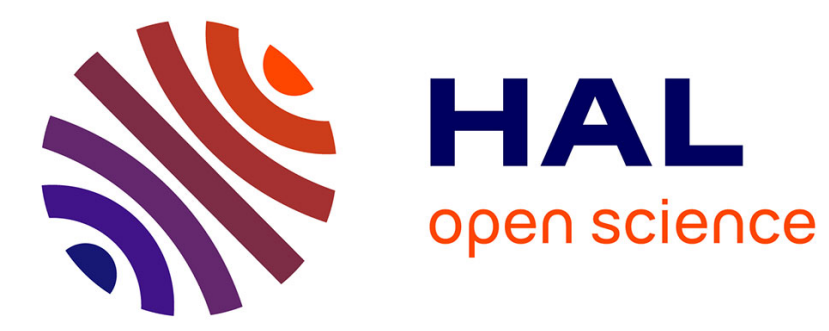

\title{
X-Ray Diffraction and X-Ray Absorption Spectrocopic Analyses for the Ruthenium Perovskites
}

\author{
J.-H. Choy, S.-H. Hwang, G. Demazeau, D.-Y. Jung
}

\section{To cite this version:}

J.-H. Choy, S.-H. Hwang, G. Demazeau, D.-Y. Jung. X-Ray Diffraction and X-Ray Absorption Spectrocopic Analyses for the Ruthenium Perovskites. Journal de Physique IV Proceedings, 1997, 7 (C2), pp.C2-763-C2-764. 10.1051/jp4:1997230 . jpa-00255309

\section{HAL Id: jpa-00255309 https://hal.science/jpa-00255309}

Submitted on 1 Jan 1997

HAL is a multi-disciplinary open access archive for the deposit and dissemination of scientific research documents, whether they are published or not. The documents may come from teaching and research institutions in France or abroad, or from public or private research centers.
L'archive ouverte pluridisciplinaire HAL, est destinée au dépôt et à la diffusion de documents scientifiques de niveau recherche, publiés ou non, émanant des établissements d'enseignement et de recherche français ou étrangers, des laboratoires publics ou privés. 


\title{
X-Ray Diffraction and X-Ray Absorption Spectrocopic Analyses for the Ruthenium Perovskites
}

\author{
J.-H. Choy, S.-H. Hwang, G. Demazeau* and D.-Y. Jung** \\ Department of Chemistry, Center for Molecular Catalysis, Seoul National University, Seoul 151-742, \\ Korea \\ * Institut de Chimie de la Matière Condensée de Bordeaux (ICMCB), 33600 Pessac cedex, France \\ ** Beckman Institute, Urbana IL 61801, U.S.A.
}

\begin{abstract}
According to the Rietveld refinements and X-ray absorption studies at the Ru K-edge, it is found that three compounds $\mathrm{La}_{2} \mathrm{BRuO}_{6}(\mathrm{~B}=\mathrm{Li}, \mathrm{Mg}$, and $\mathrm{Zn})$ are monoclinic with space group of $\mathrm{P} 2{ }_{1} / \mathrm{n}$, and that the ruthenium ions with two oxidation states $+\mathrm{IV}\left(d^{4}\right)$ and $+\mathrm{V}\left(d^{3}\right)$ are stabilized in an octahedral site of oxide lattices. A correlation is obtained between absorption edge position and the oxidation states of ruthenium. The bond lengths of (Ru-O) for both oxidation states (RuIV and $\mathrm{Ru}^{\mathrm{V}}$ ) have been quantitatively obtained by the EXAFS analysis.
\end{abstract}

\section{INTRODUCTION}

The X-ray absorption spectroscopy(XANES/EXAFS) is sensitive to the short-range coordination about a specific element averaged over its different sites, whereas $\mathrm{X}$-ray diffraction to the long range periodicity about a specific site averaged over the different atoms. By using both techniques complimentarily, a detailed information on local geometry and electronic structure of a specific element could be obtained as reported previously[1,2], in which the X-ray absorption spectroscopic analysis for iridium perovskites has been performed. In this way, the oxidation state of transition metals could be qualitatively determined by the near edge structure and the second derivatives. The local structure and bond lengths could be estimated by the EXAFS analysis and Rietveld refinement technique very clearly.

In the present study, an attempt was made to solve the electronic and local structures of ruthenium ions with different oxidation states, +IV and +V stabilized in the perovskite oxides by using XANES and EXAFS techniques.

\section{EXPERIMENTAL}

Polycrystalline samples of $\mathrm{La}_{2} \mathrm{BRuO}_{6}(\mathrm{M}=\mathrm{Li}, \mathrm{Mg}$, and $\mathrm{Zn})$, and $\mathrm{Ba}_{2} \mathrm{YRuO}_{6}$ were prepared by calcining stoichiometric amounts of reactants $\mathrm{La}\left(\mathrm{CH}_{3} \mathrm{CO}_{2}\right)_{3}, \mathrm{ZnO}, \mathrm{Y}_{2} \mathrm{O}_{3},\left[\mathrm{MgCO}_{3} \mathrm{Mg}(\mathrm{OH})_{2} \mathrm{H}_{2} \mathrm{O}\right], \mathrm{RuO}_{2}$ and $\mathrm{Li}(\mathrm{OH}) \mathrm{H}_{2} \mathrm{O}$. The latter should be added excessively in order to compensate for the sublimed $\mathrm{Li}_{2} \mathrm{O}$ at the given reaction conditions as follow; $\mathrm{La}_{2} \mathrm{LiRuO}_{6}$ was prepared at $800^{\circ} \mathrm{C}$ and the others at $950^{\circ} \mathrm{C}$ for several days in an oxygen flow of 1 bar $\left(10^{5} \mathrm{~Pa}\right)$. An oxygen gas pressure of $2 \mathrm{kbar}(200$ $\mathrm{MPa}$ ) using a compressed gas apparatus was applied for $\mathrm{La}_{2} \mathrm{LiRuO}_{6}$ at $800^{\circ} \mathrm{C}$. In case of $\mathrm{Ba}_{2} \mathrm{YRuO}_{6}$, it was treated again at $1100^{\circ} \mathrm{C}$ in air for $48 \mathrm{~h}$ in order to obtain a single phase in the X-ray powder diffraction pattern. The X-ray absorption measurements on the $\mathrm{Ru} \mathrm{K}$-edge were carried out with synchrotron radiation by using the EXAFS facilities installed at the beam line $10 \mathrm{~B}$ of the Photon Factory, the National Laboratory for High Energy Physics(Tsukuba), operated at 2.5GeV, 260$370 \mathrm{~mA}$. All the data were recorded with a spacing of $\sim 0.3 \mathrm{eV}$ for the XANES region and $\sim 1.5 \mathrm{eV}$ for the EXAFS region in the transmission mode at room temperature, using a $\mathrm{Si}(311)$ channel-cut monochromator.

\section{RESULTS AND DISCUSSION}

Crystallographic results We have performed the Rietveld analysis for three compounds, $\mathrm{La}_{2} \mathrm{BRuO}_{6}(\mathrm{~B}=\mathrm{Li}, \mathrm{Zn}$ and $\mathrm{Mg})$. In this study, refinements based upon the integrated intensities of Bragg reflections for all three compounds were carried out in space group $P 2_{1} / n$ (No. 14) with unit cell parameter of ca. $\sqrt{2} a_{p} \times \sqrt{2} a_{p} \times 2 a_{p}$ and $\beta \approx 90.0^{\circ}$, where $a_{p}$ is the unit cell parameter of a simple cubic perovskite, thus allowing for an ordered arrangement of cations over the $B$-sites. And it should be noted that the lattice parameters can be considered as those of a pseudo-orthorhombic lattice, and the B-site cation retains the bodycentered orthorhombicity in this space group, but only the lanthanum and oxygen ions lost the orthorhombic symmetry, so that the lattice symmetry was reduced to a monoclinic one. The ideal atomic coordinates were used as starting values in the Rietveld refinements. After successive refinements of the profile parameters(U, V, W, NA, NB, P), the positional parameters for lanthanum and then for oxygens and the isotropic thermal factors for all ions, the Rietveld refinement converged to the Rwp factors of 7.1\%, 5.41\%, and 6.98\% for $\mathrm{La}_{2} \mathrm{MgRuO}_{6}, \mathrm{La}_{2} \mathrm{ZnRuO}_{6}$, and $\mathrm{La}_{2} \mathrm{LiRuO}_{6}$, respectively.

X-ray Absorption spectroscopy The Ru K-edge XANES spectra and their second derivatives for the present compounds are quite similar as shown in Figure 1. This indicates that the local structure of ruthenium ion in each compound is almost the same as nearly regular octahedron, since XANES spectral shape is dependent on the local structure around the absorber ion. Thus it can be easily understood that even in $\mathrm{La}_{2} \mathrm{BRuO}_{6}(\mathrm{~B}=\mathrm{Li}, \mathrm{Mg}$, and $\mathrm{Zn})$ with monoclinically distorted lattice, a distortion in short range order- $\mathrm{RuO}_{6}$ octahedron- is not large enough to affect XANES spectral shape. This is also confirmed 
by the absence of pre-edge peak which is assigned to the dipolar forbidden $1 \mathrm{~s} \rightarrow 4 \mathrm{~d}$ transition, since it has a large intensity due to d-p mixing or quadrupole allowed transition as the local structure around absorber ion is distorted from octahedron to tetrahedron[3]. On the other hand, although the shapes in XANES spectra for the present compounds are a quite similar one another, it is clearly seen that the peak positions in the main edge region shift to higher energies as the oxidation state of the ruthenium ion increases. The first peak on the main edge region assigned to dipole allowed $1 \mathrm{~s} \rightarrow 5 \mathrm{p}$ transition is different by ca. $2 \mathrm{eV}$, from ca. $22131 \mathrm{eV}$ for $\mathrm{Ru}^{+\mathrm{IV}}$ to ca. $22133 \mathrm{eV}$ for $\mathrm{Ru}^{+\mathrm{V}}$, depending upon the oxidation states $(+\mathrm{IV} \&+\mathrm{V})$, and the second peak primarily caused by the continuum shape resonance effects shows similar tendency.

It is also of great interest to examine quantitatively the change of Ru-O bond distances depending on the oxidation states of the ruthenium ion in comparison with earlier diffraction results. The determination of the metal-oxygen bond distance by means of EXAFS spectroscopy might be quite instructive because the ruthenium ions in all compounds exist in only one site, so that the first shell for the nearest neighbor of oxygen around the central metal is well separated from the other distant shells in perovskites. The $\mathrm{k}^{3}$-weighted Ru K-edge EXAFS spectra for the present perovskite compounds are shown in Figure 2 (A) and their Fourier transforms(open circle) and best fits(solid line) in the range of $\sim 3 \AA^{-1} \leq k \leq \sim 13 \AA^{-1}$ in Figure 2 (B). The first peak in the Fourier transforms is attributed to the Ru-O bonding pair. The fitting results for the first shell are presented in table 1 in comparison with diffraction results. The Ru-O bond distances were in relatively good agreement with the crystallographic results and show the tendency to decrease depending upon the increase of oxidation state of the ruthenium ion. On the other hand, the Ru-O bond distance in case of the same oxidation state show a little difference. These differences could be explained by considering the competing bond effect. The Ru-O bond distance in $\mathrm{La}_{2} \mathrm{MgRuO}_{6}$ is shorter than that in $\mathrm{La}_{2} \mathrm{ZnRuO}_{6}$, which can be understood from the fact that the ionicity of the $\mathrm{Mg}-\mathrm{O}$ bond is larger than that of the $\mathrm{Zn}-\mathrm{O}$ bond. In addition, the shorter $\mathrm{Ru}-\mathrm{O}$ bond distance in $\mathrm{La}_{2} \mathrm{LiRuO}_{6}$ compared to that in $\mathrm{Ba}_{2} \mathrm{YRuO}_{6}$, can also be understood since the former has the smaller A-site cation and weaker competing bond (Li-O).

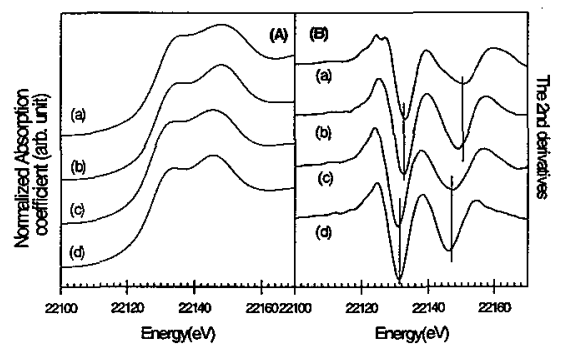

Figure 1: Ru K-edge XANES (A) spline and (B) 2nd derivative spectra for (a) $\mathrm{Ba}_{2} \mathrm{YRu}^{\mathrm{V}} \mathrm{O}_{6}$, (b) $\mathrm{La}_{2} \mathrm{LiRu}^{\mathrm{v}} \mathrm{O}_{6}$, (c) $\mathrm{La}_{2} \mathrm{MgRu}^{\mathrm{V}} \mathrm{O}_{6}$, and (d) $\mathrm{La}_{2} \mathrm{ZnRu}^{\mathrm{IV}} \mathrm{O}_{6}$.

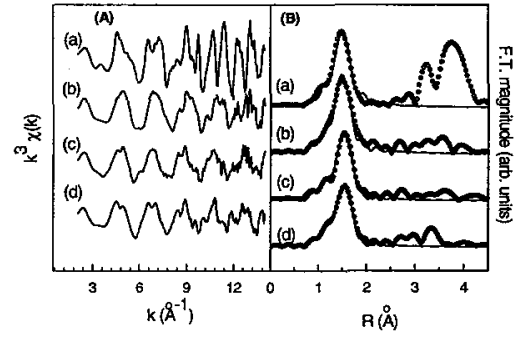

Figure 2: (A) The $\mathrm{k}^{3}$-weighted EXAFS spectra and (B) their Fourier transforms (open circle) and best fits (solid line) for (a) $\mathrm{Ba}_{2} \mathrm{YRu}^{\mathrm{v}} \mathrm{O}_{6}$, (b) $\mathrm{La}_{2} \mathrm{LiRu}^{\mathrm{V}} \mathrm{O}_{6}$, (c) $\mathrm{La}_{2} \mathrm{MgRu}^{\mathrm{NV}} \mathrm{O}_{6}$, and (d) $\mathrm{La}_{2} \mathrm{ZnRu}^{\mathrm{IV}} \mathrm{O}_{6}$.

Table 1. Structural parameters for (Ru-O) bond obtained from EXAFS analyses.

\begin{tabular}{|c|c|c|c|c|}
\hline Prym con & 7) amplivere & Debye- Waile & 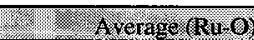 & ond distaree $(1)$ \\
\hline (2. & 1 (1) & tactar $\left(\times 10^{3} 92\right)$ & 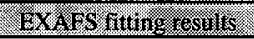 & Crystallograbio dat \\
\hline $\mathrm{La}_{2} \mathrm{MgRuO}_{6}$ & 0.86 & 2.89 & $1.99_{1}$ & 2.024 \\
\hline $\mathrm{La}_{2} \mathrm{ZnRuO}_{6}$ & 0.86 & $3.3 i$ & $1.99_{6}$ & 2.026 \\
\hline $\mathrm{La}_{2} \mathrm{LiRuO}_{6}$ & 0.91 & $2.4_{6}$ & $1.94 \mathrm{~g}$ & 1.910 \\
\hline $\mathrm{Ba}_{2} \mathrm{YRuO}_{6}$ & 0.88 & 2.63 & $1.95_{3}$ & $1.954[4]$ \\
\hline
\end{tabular}

\section{ACKNOWLEDGMENT}

This work was in part supported by the grant for international cooperation of the Korean Science and Engineering Foundation and by the Center for Molecular Catalysis. Authors are grateful to Prof. M. Nomura for helping us to get the XAS data at the Photon Factory.

\section{REFERENCES}

[1] Choy J. H., Kim D. K., Demazeau G., Jung D. Y., J. Phys. Chem. 98 (1994) 6258.

[2] Choy J. H., Kim D. K., Hwang S. H., Demazeau G., Jung D. Y., J. Am. Chem. Soc. 117 (1995) 8557.

[3] Hahn J. E., Scott R. A. , Hodgson K. O., Doniach S., Desjardins S. R., Solomon E. I,, Chem. Phys. Lett. 88 (1982) 595.

[4] Battle P. D., Jones C. W., J. Solid State Chem. 78 (1989) 108. 